\title{
Seventy-five years of cardiovascular rehabilitation in Mexico
}

\author{
Setenta y cinco años de rehabilitación cardiovascular en México
}

Jessica Rojano-Castillo ${ }^{1 *}$, Hermes Ilarraza-Lomelí1, Juana Zavala-Ramírez², Raúl Cantero-Colín ${ }^{3}$, Azucena Rodríguez-Reyes ${ }^{4}$, Rodolfo Lerma-Espinosa ${ }^{5}$, Marcela Mancilla-Pérez ${ }^{1}$, María D. Rius-Suáreż and Marianna A. García-Saldivia ${ }^{3}$

${ }^{1}$ Cardiac Rehabilitation and Physical Medicine, Instituto Nacional de Cardiología Ignacio Chávez; ${ }^{2}$ Cardiac Rehabilitation, Instituto Nacional de Rehabilitación; ${ }^{3}$ Cardiac Rehabilitation, Cardiology Hospital, Centro Médico Nacional Siglo XX, IMSS; ${ }^{4}$ Cardiac Rehabilitation, Hospital General Naval de Alta Especialidad; ${ }^{5}$ Cardiac Rehabilitation, Hospital Central Militar, Mexico City, Mexico

\begin{abstract}
Patients suffering from cardiovascular disease require comprehensive medical attention that involves therapies and procedures necessary to reintegrate them optimally to their personal, family, work, and social life. Interventions aimed at achieving these.goals are included in cardiac rehabilitation programs. These programs are designed to limit the harmful physiological and psychological effects of heart disease, reduce the risk of sudden death or reinfarction, control cardiovascular symptoms, stabilize or reverse the atherosclerosis process, and improve the psychosocial and vocational status of patients. These programs have existed in Mexico since the 1940s and have evolved over the years, adapting to the disease conditions present in our country, starting with therapies to treat patients with rheumatic heart disease until the application of physical exercise in patients with heart failure complexes congenital heart disease or pulmonary arterial hypertension. These activities are of a transdisciplinary nature and involve the integration of cardiologists, physiotherapists, psychologists, and nutritionists among others. At present, these programs have spread throughout the Mexican Republic thank rehabilitation cardiologists graduating from the main health institutions in the country such as health institutes, Mexican Social Security Institute, and Institute of Security and Social Services of State Workers. In this document, the origins of rehabilitation from the pre-Hispanic era to the present will be discussed, highlighting the contributions in teaching and research of the physicians who have practiced in this area in the aforementioned institutions.

Key words: Cardiac rehabilitation. Cardiovascular prevention. Mexico. Cardiology. Heart attack. Physiotherapy.

\section{Resumen}

Los pacientes que sufren una enfermedad cardiovascular requieren de atención médica integral que involucre las terapias y procedimientos necesarios para reintegrarlos de forma óptima a su vida personal, familiar, laboral y social. Las intervenciones
\end{abstract}

\section{Correspondence:}

*Jessica Rojano-Castillo

E-mail: jessy.roc@ @otmail.com

license (http://creativecommons.org/licenses/by-nc-nd/4.0/)
Date of reception: 05-03-2019

Date of acceptance: 26-06-2019

DOI: 10.24875/ACME.M19000057
Available online: 02-10-2019 Arch Cardiol Mex (Eng). 2019;89(3):233-241

www.archivoscardiologia.com 
dirigidas a alcanzar dichas metas se incluyen en los programas de rehabilitación cardiaca. Estos programas son diseñados para limitar los efectos dañinos tanto fisiológicos como psicológicos de las cardiopatías, reducir el riesgo de muerte súbita o reinfarto, controlar la sintomatología cardiovascular, estabilizar o revertir el proceso de aterosclerosis y mejorar el eśtado psicosocial y vocacional de los pacientes. Dichos programas existen en México desde la década de 1940 y han evoluciônado a lo largo de los años, adaptándose a las condiciones de enfermedad presentes en nuestro país, desde su inicio con terapias para tratar a pacientes cardiopatía reumática hasta la aplicación del ejercicio físico en pacientes con insuficięhcia cardiaca, cardiopatías congénitas complejas o hipertensión arterial pulmonar. Estas actividades son de índole transdisciplinaria e implica la integración de cardiólogos, fisioterapeutas, psicólogos y nutriólogos, entre otros. Actualmente, estos programas se han extendido a lo largo de la República Mexicana gracias a cardiólogos rehabilitadores egresados dê las principales instituciones de salud del país, como son los Institutos de Salud, el IMSS (Instituto Mexicano del Seguro Sö́cial) y el ISSSTE (Instituto de Seguridad y Servicios Sociales para los Trabajadores del Estado). En este documento se expondrán los orígenes de la rehabilitación, desde la época prehispánica hasta la actual, destacando las contribuciones en docencija $e$ investigación de los médicos que han ejercido en esta área en las instituciones previamente mencionadas.

Palabras clave: Rehabilitación cardiaca. Prevención cardiovascular. México. Cardiología. Infarto. Fisioterapia.

Quicemitqui in yollotli... (the heart governs everything). Florentine codex.

A patient that is discharged from the hospital after having suffered a cardiovascular event continues his or her convalescence process at home, where he/she will fully recover. With the purpose to support the patient in this process, specifically directed interventions by means of cardiovascular rehabilitation and prevention programs (PRPCV - Programas de Rehabilitación y Prevención Cardiovascular) have been developed since many years ago. In 1964, the World Health Organization (WHO) published its first operational definition of this kind of program. Later, in the decade of 1980, Feigenbaum masterfully described cardiac rehabilitation as "... long-term programs comprising medical evaluation, physical exercise prescription, risk factors' modification, education, and patient advice. These programs are designed to limit the harmful effects, both physiological and psychological, of heart disease, to reduce the risk of sudden death or reinfarction, control cardiovascular symptomatology, stabilize or reverse the atherosclerotic process, and improve psychosocial and vocational status of patients"1.

These transdisciplinary activities seek the reintegration of the patient to his/her daily life, in the most comprehensive and expeditious way possible, based on physical training, education, and professional advice. Physical exercise has been used for medicinal purposes for thousands of years by civilizations such as the Egyptians or the Greeks. Hippocrates stressed that walking was the best medicine for man $^{2}$. In Mexico, since our ancestors, we have recognized the heart as a vital organ that requires study and care. Hence, the present manuscript seeks to relate some of the significant historical facts that have made cardiovascular rehabilitation a current and relevant cardiologic specialty.

"Our heart gives life, supports, beats."

Fray Bernardino de Sahagún.

In the pre-Hispanic era, the heart was considerea as a link between the material and the spiritual reafms. Thus, constant beat (motlatlamotla) was synonymous with movement of life (iolli). Since then, heartbeat was considered to be a cyclical event (yóllotl), which we today call the cardiac cycle. Fray Bernardino de Sahagún related that, for the natives, the heart represented the source of energy and vigor for the human being. This reminds us of the modern description that the Swedish scientist Per-Olof Astrand would make inthe $20^{\text {th }}$ century when conducting his investigations on the bodily use or consumption of oxygen $\left(\mathrm{VO}_{2}\right)^{3}, \stackrel{4}{\subset} \mathrm{Cn}$ the other hand, the Cruz-Badiano codex (Libellus $d e$ medicinalibus indorum herbis, 1552) describes cafdiovascular symptoms as the "unpleasant oppression of chest, heart pain, or heartbeat," and explains the- $u$ se of herbalism for the treatment of said ailments. The absence of stories on any kind of preventive measure draws the attention ${ }^{4}$.

Although physical training was not used for therapeutic purposes, the Aztec people appreciated its effect during the training of their warriors and messengers (painanis), by providing them with outstanding physjical abilities ${ }^{5}$. It should be noted that, apparently, these-people treated with respect to those who suffered any kind of deformity or disability, who were socially included $\%$.

Once our country was constituted as such, in $1 \overline{8} 69$, in the Military Health Service, at the Military Hospital, the use of physical therapy for patients with disabilities, particularly with the use of medicinal baths, is recorded for the $1^{\text {st }}$ time ${ }^{7}$. On the other hand, there are reports 
that a couple of decades later, in Leipzig, reports appeared on the use of physical training for the care of patients with cardiovascular disease (Oertel, 1891) ${ }^{8}$.

In the world, the following years were marked by social turmoil, such as the Mexican and the Russian revolutions, as well as countless armed conflicts headed by two world wars. This caused unavoidable political and financial instability. In the next paragraphs, we will describe some of the most important decades of the $20^{\text {th }}$ century and their relationship with cardiovascular rehabilitation programs.

\section{The 1940s decade}

In those days, there were barely over 6000 doctors in Mexico, and several institutions were created, such as the Ministry of Health, the National Institutes of Health, and the Mexican Institute of Social Security (IMSS - Instituto Mexicano del Seguro Social) $)^{9}$. It was on April 18, 1944, the day the National Institute of Cardiology of Mexico (INCICh - Instituto Nacional de Cardiología Ignacio Chávez) was officially opened, when Professor Ignacio Chávez would entrust the creation of the cardiovascular rehabilitation and physical medicine area to his brother, Dr. Nicandro Chávez Sánchez, pioneer of physical medicine in the country, together with Dr. Alfonso Tohen Zamudio (Children's Hospital of Mexico, 1943) and Dr. Leopoldo Melgar Pachiano (Military Hospital, 1946).

In those days, rheumatic fever wreaked havoc in the population and demanded the development of new modalities for diagnosis and treatment of these patients, mostly based on specific lines of research. Dr. Nicandro Chávez published a study showing the use of iontophoresis with salicylates in patients with acute rheumatic pancarditis ${ }^{10}$. It was he who also developed the "artificial fever rooms," considering that they would accelerate the recovery of patients. Figure 1 shows Dr. Nicandro Chavez with Professors Ignacio Chavez and Enrique Cabrera.

\section{The 1950 s and 1960s decades}

The arms race between the capitalist and socialist blocks was just starting, while rheumatic heart disease and its sequels remained a public health problem. Cardiology was growing along with novel methods of study and treatment such as intensive care and coronary care units, cardiac surgery with cardiopulmonary bypass pump, and the first heart transplant ${ }^{11}$. Mexico was at the forefront of world cardiology in topics such as

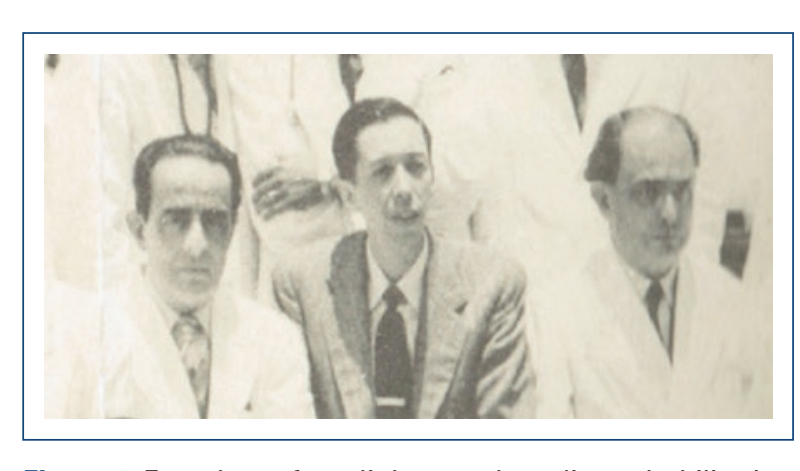

Figure 1. Founders of cardiology and cardiac rehabilitation in Mexico. From left to right: Dr. Nicandro Châyez, Dr. Enrique Cabrera, and Dr. Ignacio Chávez Sánchez.

physiology, pharmacology, and electrocardiography. Cardiovascular rehabilitation remained without many changes ${ }^{12}$. In the 1960 s, ischemic heart disease abruptly entered the cardiologic agenda, and myocardial infarction began to be associated with atherosclerosis and dyslipidemia ${ }^{13}$. At the same time, several researchers highlighted the reduction of mortality through early mobilization (EM) of patients with myocardial infarction. On the other hand, sedentary subjects, such as London bus drivers, were observed to be at higher risk of developing heart conditions in comparison with more active individuals, such as the collectors of these vehicles, who were constantly moving ${ }^{14,15}$. It was in this decade when the WHO defined cardiac rehabilitation (vide supra), a fact that would attract the eyes of mu(tiple researchers interested in the usefulness of physical training for patients with coronary artery disease ${ }^{16,4}$.

\section{The 1970s decade}

This era was marked by the beginning of an endless financial crisis. In those days, cardiology saw the birth of one of the most important milestones of science in the $20^{\text {th }}$ century: thrombolysis therapy during acute myocardial infarction. Cardiac rehabilitation programs focused on the management of bedridden patients, seeking EM, mainly due to a prolonged hospital stay and, naturally, specific interest in the management of patients with coronary heart disease was arising ${ }^{18,19}$.

In this era, new actors were incorporated, such as Dr. Juan Enrique Quintal Velazco, specialist in rehabilitation, who had a brief stay at the National Institute of Cardiology to continue as chief of department at hospitals such the General Hospital of Mexico, the Lôpez Mateos Hospital, and the 20 de Noviembre Hospital Center, which belongs to the Institute of Social Securrity and Services for State Workers (ISSSTE - Instituto de 
Seguridad y Servicios Sociales de los Trabajadores del Estado). In the latter institution, the department of cardiovascular rehabilitation was founded in $1974^{20,21}$.

Concurrently, on August 1, 1975, cardiologist Jorge Escudero de la Peña would start the cardiovascular rehabilitation program activities at the IMSS, within the facilities of what formerly was the Hospital of Chest Diseases, currently the Cardiology Hospital of the National Medical Center Siglo XXI (CMNsXXI - Centro Médico Nacional Siglo XXI). Early on that decade, Nicandro Chávez retired from the INCICh and was replaced by Pedro Fernández de la Vega and later by Jorge Marcushamer. The cardiovascular rehabilitation programs were acquiring a multidisciplinary structure that brought together the work of doctors, nurses, and physiotherapists on three phases: in hospital (I), at the hospital with outpatients (II), and domiciliary (III) 22 .

Research in Mexican cardiovascular rehabilitation centers focused on EM, physical training in subjects with ischemic heart disease, heart failure, post-revascularization surgery, and post-coronary intervention, as well as on primary and secondary prevention. At the same time, protocols on the use of exercise testing in different types of patients were developed and works were published on adaptation of some sports for the training of patients on cardiovascular rehabilitation (volleyball), on the establishment of clinics for smoking cessation, on the role of psychology and social work in these programs, and on the effect of cardiovascular rehabilitation on return to work. Figure 2 shows the publications made throughout these 75 years of history, classified by institution and type of publication.

\section{The 1980s decade}

These years were represented by the end of the Cold War, the fall of the Berlin Wall, and the dismantling of the Soviet Union as a result of Mikhail Gorbachev's opening (Perestroika). Furthermore, in this decade, the first cardiac defibrillators were implanted and the first angioplasties were performed ${ }^{23}$.

Cardiovascular rehabilitation was formally integrated into cardiovascular prevention programs, consolidating robust physical and education training programs, primarily focused on patients with ischemic heart disease. In the European Society of Cardiology, the working group headed by the Scandinavian countries, Germany, Switzerland, and Spain dominated the panorama in the old continent, whereas in the US, Froelicher and Humprey were the leaders ${ }^{24,25}$.

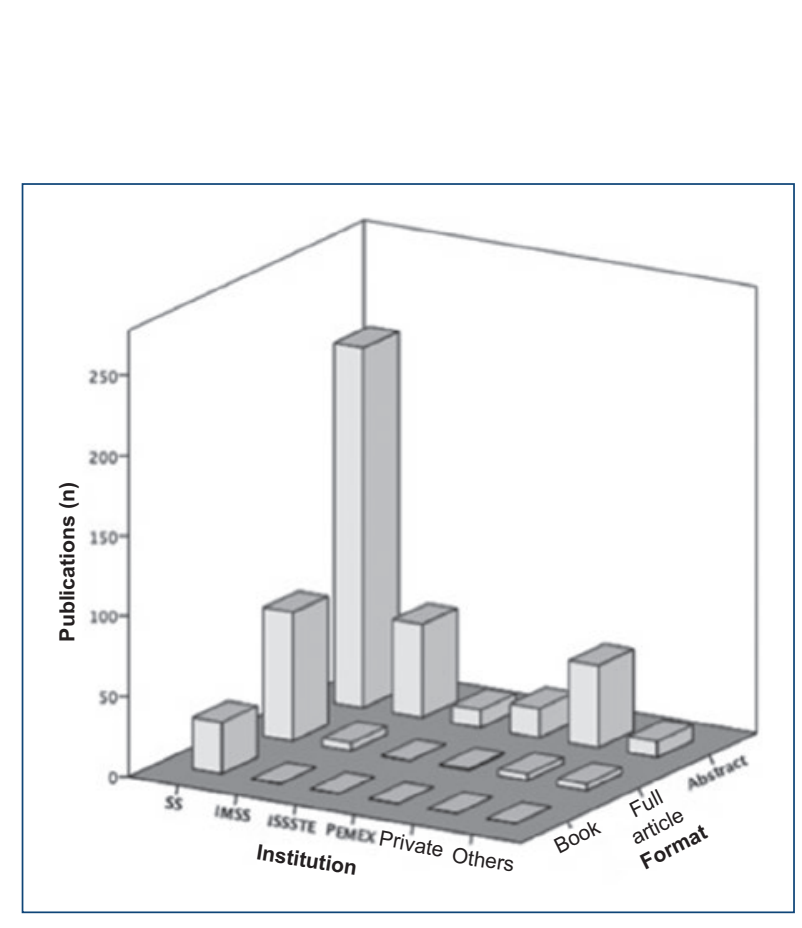

Figure 2. Research on cardiac rehabilitation. Publications by institution and type: books, full articles, or free works in congresses. SS: Health Services (includes the National Institute of Cardiology Ignacio Chavez, National Rehabilitation Institute, National Institute of Medical Sciences and Nutrition Salvador Zubirán, General Hospital of Mexico, and National Institute of Pediatrīes); IMSS: Mexican Institute of Social Security; ISSSTE: Institute of Social Security and Services for State Workers.

At the INCICh, various leading personalities served at the cardiovascular rehabilitation department, "with Jorge Marcushamer, Javier Marín, Luis Méndez, Jesús A. González Hermosillo, Ma. Guadalupe Hernández, Jorge Hernández, Luis Villamar and Juana Pinêda, Marcela Pérez and Sofía Bouchet, among others, standing out. In those days, the first cardiopulmonary exercise tests were performed with the use of the Douglas bag. Teaching programs specialized in cardiovascular rehabilitation were initiated, both for cardiologists and for nurses and physiotherapists ${ }^{26}$.

At CMNsXXI-IMSS, Edmundo Pombo replaced Juan Rivera as head of the cardiovascular rehabilitation $>$ department, and in those days, the also cardiologist Héctor Hernández y Hernández, nurse Socorro Olvera, electrodiagnostic technician Roberto González, and physiotherapists Margarita Marín, Amira Morales, and Patricia Rosas joined the department. In the year 1985, Dr. Hernáñdez replaced Dr. Pombo as head of the department.

\section{The 1990s decade}

This decade saw the birth of the European Union and the novelty in communications known as the Internet. 
Interventional procedures were already in vogue and cardiovascular prevention was increasingly acquiring presence ${ }^{27}$. Several cardiovascular rehabilitation departments arose in various public and private institutions of our country.

The first census of cardiac rehabilitation centers in Mexico was carried out in 1993 and presented at the National Congress of Cardiology in the city of Veracruz. The results were presented in a poster that identified eight centers specialized in cardiovascular rehabilitation, where programs on physical training (37\%), patient and family education (62\%), stress management (50\%), nutrition (37\%), anti-smoking clinic (12\%), labor advice $(25 \%)$, and advice on sexual activity (50\%) were offered $^{28}$.

Gabriel Vázquez-Cabrer ran the cardiovascular rehabilitation program at the INCICh and implemented, together with Nurse Guadalupe Pinson, a program based on his experience acquired in units of Spain, Germany, and the USA. In those days, the effect of physical training in patients with heart failure, post-revascularization, patient reintegration to work, and patient quality of life was studied. At the end of the decade, Bonifacio Mendoza replaced Gabriel Vázquez. Many physicians, physiotherapists, and nurses from the country and abroad received academic training on cardiovascular rehabilitation at the INCICh.

At CMNsXXI-IMSS, the department was integrated by cardiologists Héctor Hernández, Patricia Camacho, and Noemí Contreras and physiotherapist René Cámara, among others. Their patients with valvular disease, congenital heart disease, systemic arterial hypertension, and coronary interventional procedures were treated. That decade was of development, both in the physical area and in the incorporation of personnel in physical medicine, psychiatry, endocrinology, physiotherapy, electrodiagnosis, nursing, social work, and nutrition. In 1991, the physiotherapists in cardiac rehabilitation chapter from the National Association of IMSS Cardiologists (ANCIMSS), currently, the National Association of Cardiologists of Mexico (ANCAM), were created.

In 1992, Gabriel Cherebetiu, a Romanian doctor, pioneered the specialty of sports medicine in our country and founded the Cardiovascular Rehabilitation Department at Hospital Angeles del Pedregal, as part of the Department of Cardiovascular Physiology, which he directs since then. In 1994, the Mexican Association of Cardiovascular and Pulmonary Rehabilitation A.C, first of its kind in our country, was founded.
Cardiologist Manuel Antonio Leyva Gómez started in 1995 the Cardiovascular Rehabilitation Unit at Soluth Central Hospital of Petróleos Mexicanos (PEMEX) medical services and actively participated in several academic activities along with other institutions.

On that same year, the cardiovascular rehabilitation program was started at the National Institute of Rehabilitation (INR - Instituto Nacional de Rehabilitación) by doctor in rehabilitation Juana Zavala Ramírez, cardiologist Luis Jesús San Juan Rivas and Víctor Suărez, psychologist Angélica Ayala Balcázar, and therapists Mónica Garza Hevia, Maira Mar Fadanelli, Graciela Valero, Carmen Rosales, and Martha Ríos. Carmen Gutiérrez de Velasco was then the head of the geriatric and cardiorespiratory rehabilitation division. A couple of years later, the Cardiovascular Rehabilitation Department was created at the Naval Medical Center by cardiologist Héctor Sánchez Sierra together with Nurse Hugolina Márquez de La Paz (July 1, 1997).

By the end of the decade, Macías Hidalgo published various works on the rehabilitation program that he was running at IMSS CMN Hospital of cardiovascular and chest diseases in the city of Monterrey, NL, with the main research topics being physical training in patients with heart disease and its effect on quality of life, adherence to cardiovascular rehabilitation programs, and coronary disease early detection in women.

\section{From the year 2000 to the present day}

The arrival of the new millennium was accompanied by the global economic crisis, war on terrorism, anर्कthe creation of smartphones, which have revolutionized communications at the personal level. In the Mexican Republic, there was an unheard-of political transition and Vicente Fox took possession as the opposition president of the country.

At the National Institute of Cardiology, Hermes dlarraza Lomelí was appointed the head of the department and adapted a cardiovascular rehabilitation and prevention program based on the European Schoot of countries such as Switzerland, Spain, Germany, Sweden, and Italy. This transdisciplinary program includes the three areas of medical tasks: care, teaching, and research. To the previously established lines of $r$ research, the study of cardiopulmonary exercise testing, risk stratification calculators, physical training in "children with heart disease and very high-risk patients, application of the sciences of complexity, perception of effort, and adaptation of new modalities of physical 


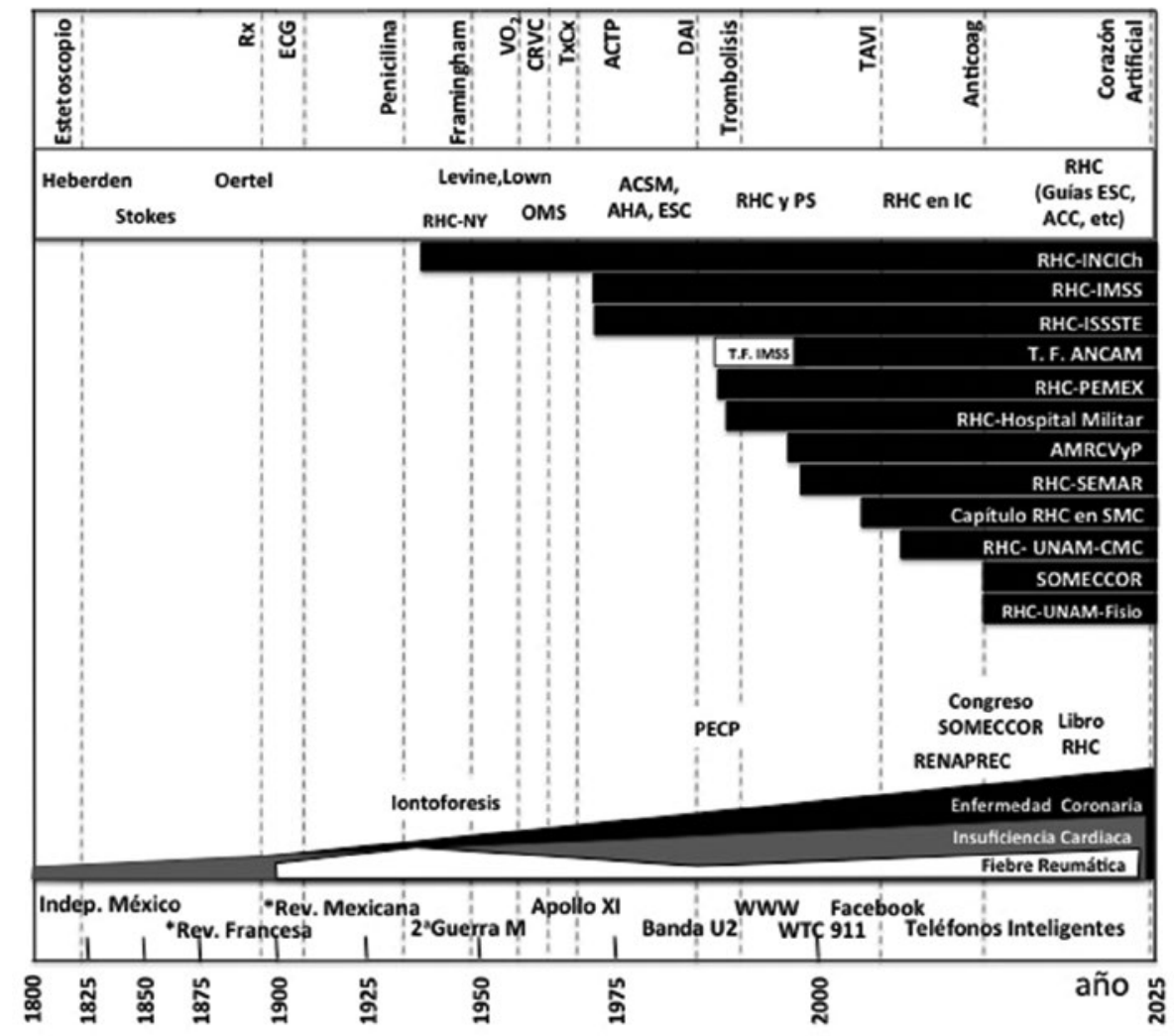

Figure 3. Cardiac rehabilitation chronology in the history of cardiology, Mexican history, and universal history. Horizontal axis: at the bottom: groups of 25 years, starting in 1800 and projecting to 2025 . On the same horizontal axis, in the immediate line above the years: some of the important events of universal history and Mexico. Top of the figure: some events that changed the history of medicine and cardiology (invention of the stethoscope, Rx, ECG, among others); in the top horizontal white bar, far left: famous personalities and events in the history of world cardiac rehabilitation, starting with Sir Wilijam Heberden; right end: cardiac rehabilitation guidelines from the main cardiology societies; figure center: institutions $\overline{\text { with }}$ cardiac rehabilitation available; left end of the bar: year of the opening of the cardiac rehabilitation department at each institution, as well as the years of the founding of the cardiac rehabilitation chapter at the Mexican Society of Cardiology, recognition by the Mexican Cardiology Council, founding of the Mexican Society for Heart Care (SOMECCOR), and recognition by the National Autonomous University of Mexico (UNAM) of cardiac rehabilitation high specialty courses for cardiologists and the physiotherapy in cardiac rehabilitation diploma course; below the bars of the institutions: key events in cardiac rehabilitation, such as iontophoresis, introduction of the use of cardiopulmonary stress testing, first National Registry of Cardiac Rehabilitation Programs in Mexico, first Mexican Cardiac Rehabilitation Congress, Prevention and Cardiology of Sport, and books on cardiac rehabilitation; below the cardiac rehabilitation events in Mexico, marked in white, gray, and black: main pathologies that are investigated in cardiology according to PubMed publications. Estetoscopio: stethosconpe; Rx: X-rays; ECG: electrocardiogram; V0: oxygen consumption; CRVC: coronary artery bypass graft; TxCx: heart transplant; ACTP: first angioplasty; DAl: first defibrillator; trombolisis: thrombolysis; TAVI: transcatheter aortic valve replacement; anticoag: anticoagulation; Corazón Artificial: artificial heart; RHC-NY: cardiac rehabilitation in New York; ACSM: American College of Sports Medicine; AHA: American Heart Association; ESC: European Society of Cardiology; RHCyPS: cardiac rehabilitation and secondary prevention; $R H C$ en IC: cardiac rehabilitation in heart failure; RHC: cardiac rehabilitation; Guías: guidelines; ACC: American College of Cardiology, INCICh: National Institute of Cardiology Ignacio Chavez; IMSS: Mexican Institute of Social Security; ISSSTE: Institute of Social Security and Services for State Workers; TF: physical therapy; ANCAM: National Association of Cardiologists of Mexico; PEMEX: Petróleos Mexicanos; AMRCVyP: Mexican Cardiovascular and Pulmonary Rehabilitation Association; SEMAR: Ministry of the Navy; Capitulo: chapter; SMC: Mexican Society of Cardiology; CMC: Mexican Council of Cardiology; UNAM: National Autonomous University of Mexico; Fisio: physiotherapy; Congreso: congress; SOMECCOR: Mexican Society for Heart Care; PECP: cardiopulmonary stress testing; RENAPREC: National Registry of Cardiac Rehabilitation Programs; Libro: book; Iontoforesis: iontophoresis; Enfermedad Coronaria: coronary artery disease; Insuficiencia Cardiaca: heart failure; Fiebre Reumática: rheumatic fever; Indep. México: Mexican independence; Rev. Francesa: French revolution; Rev. Mexicana: Mexican revolution; $2^{a}$ Guerra M: WEorld War II; Banda U2: U2 band; Teléfonos Inteligentes: Smartphones; año: year. 
activity, such as ballroom dancing or modified tennis, were incorporated.

Cardiac rehabilitation high specialty university programs, focused on the training of doctors, first included rehabilitation medicine specialists (INR-2006) and later cardiologists (UNAM, 2007), with dozens of residents having graduated so far. Similarly, the cardiovascular rehabilitation training course for physiotherapists is endorsed by the UNAM since 2014.

Both programs are available at CMNsXXI-IMSS. These courses, with theoretical and practical modality and an adequate burden of assistance work, constitute unique global models for the raining of this kind of human resources. In 2012, the Mexican Council of Cardiology awarded cardiac rehabilitation and secondary prevention programs the certificate of suitability as high specialty training in cardiology. At the CMNsXXI-IMSS, Rodolfo Herrera was appointed the head of the department and incorporated cardiovascular rehabilitation to the heart transplant program. Other doctors who stood out at the IMSS and that promoted the development of cardiac rehabilitation in this institution were Samuel Justiniano, Raúl Cantero, Jorge Hilario Jiménez, and Daniel Gasca.

At the Mexican Navy medical services, José Luis Álvarez Cabrera continued Héctor Sánchez Sierra's work as head of cardiovascular rehabilitation, along with Carlos Buenfil. When the new facilities of the High Specialty Naval General Hospital (HOSGENAES Hospital General Naval de Alta Especialidad) were opened in 2008, the direction of the department remained in the hands of cardiologist Joel Álvarez Peña, who was later replaced by Azucena Rodríguez ${ }^{29}$.

In 2006, rehabilitation specialist Dr. Álvaro Lomelí Rivas joined the National Institute of Rehabilitation as head of the division and managed to start the high specialty in cardiac rehabilitation, with Juana Zavala participating as associate professor. The INR specializes in the care of patients with cardiovascular disease and different types of disability, particularly patients with lower limb amputations. Subsequently, this team was joined by cardiologist Francisco Ramos. A few years later, Juana Zavala became head of the specialty and was later replaced by Ángela Solache Carranco and subsequently by Roberto Carlos Sahagún Olmos.

The cardiac rehabilitation chapter was founded in March 2003 at the Mexican Society of Cardiology, and it has had an active participation both in statutory sessions and in national congresses.

In May 2013, the Mexican Society for Heart Care (SOMECCOR) was set up, with the mission of carrying out the study, research, teaching, exercise, dissemination and application of knowledge on cardiovascular rehabilitation, sports cardiology, and related sciences. Throughout these years, more than 60 ordinary ầcademic sessions have been held and two national congresses were carried out (León 2013 and Veracruz 2016). SOMECCOR is recognized by the Mexican Council of Cardiology as a cardiology association dedicated to update specialists and is made up of seven chapters: cardiology, rehabilitation medicine, sports medicine, nursing, physiotherapy, prevention, and nutrition-psychology ${ }^{30}$.

It is important highlighting the participation of patients in the constitution of two societies called Enfermos del Corazón A.C. and Cardiópatas Unidos A.C., with ašsociates of both the CMNsXXI and the National Instifitute of Cardiology. At present, there are several social हnetworks that offer support to this type of patients.

To date, the National Institute of Cardiology andithe CMNsXXI have increased their workforce with the incorporation of Aurora Palao and Jesús Silva to the IMSS $^{31}$ and Jessica Rojano Castillo to the INCICCh. Figure 3 summarizes the most important events in universal, cardiology, and cardiac rehabilitation history. Figure 4 includes some of the doctors, physiotherapists, and nurses who have contributed to the development of cardiac rehabilitation in Mexico.

In summary, throughout this article, we have shown how the different cardiac rehabilitation programs have emerged and evolved in our country since 1944, âs a continuous adaptation to the requirements of eachera, and have been consolidated as a fundamental part in current comprehensive treatment. The future holds many challenges, such as the consolidation of cardiovascular rehabilitation programs for patients with congenital heart disease or with pulmonary arterial hypertension, in addition to the serious problem entailed by the low reference rate of patients eligible for cardiovascular rehabilitation programs, along with the poor adherence of patients to medical treatment. Ene of the keys to face these challenges is based on the spirit of transdisciplinary teamwork focused on the resolution of problems inherent to patients with heart disease.

"We need to create by ourselves, make science by ourselves and not spend our lives praying the truths and mistakes that others bequeathed to us. As long as we fail to do this, we will be eternally left behind inthe scientists' world and eternally unable to solve our problems according to our own reality."

Prof. Ignacio Chavez 


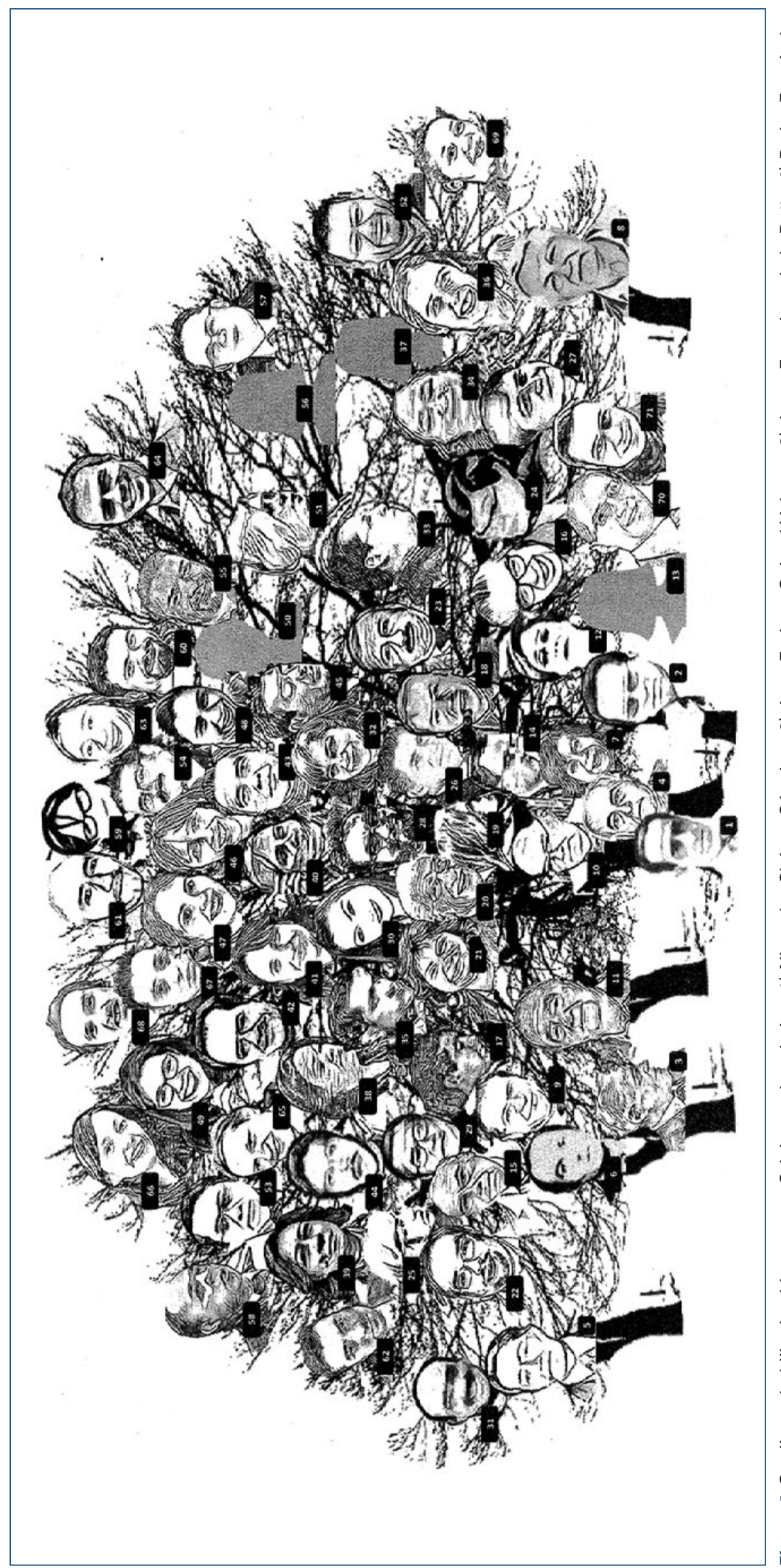

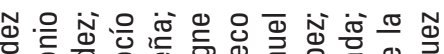

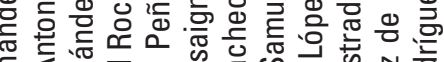
둔

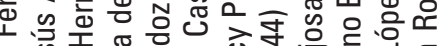

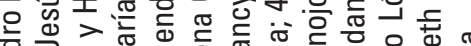

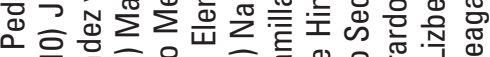

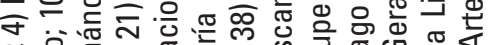

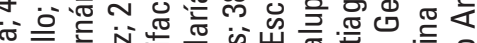

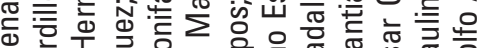
히 ప্口 ๔ర

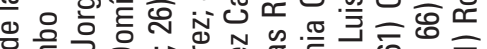

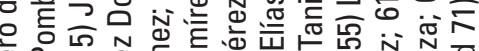

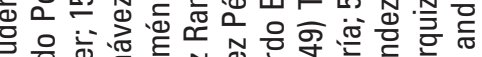

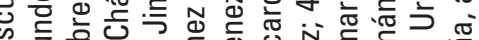

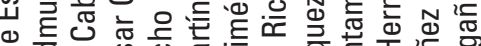

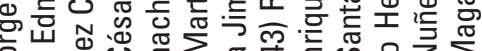

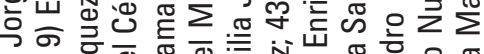
М

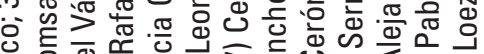
홍.

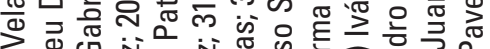

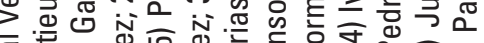

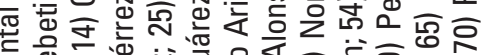

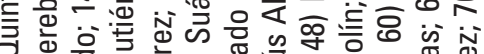

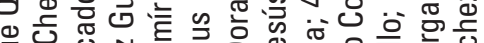

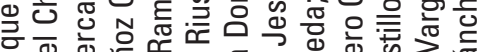

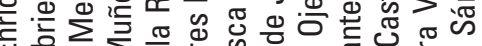

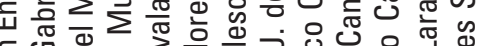

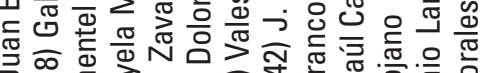
今 ล

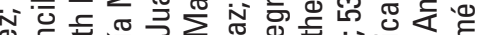

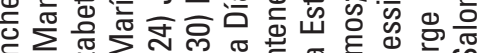
西 N N

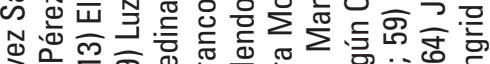

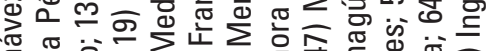
歾元

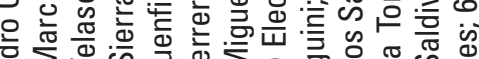

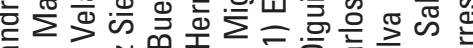

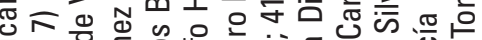

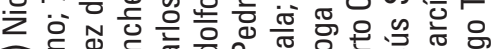
= ฮิ

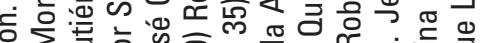

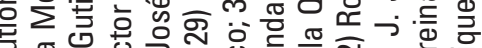
정

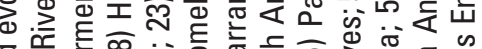

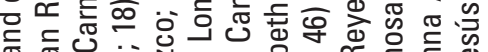
i

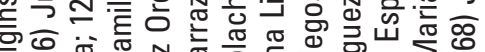

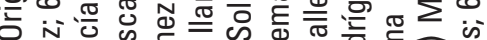

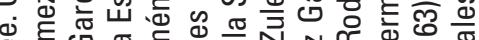
む.

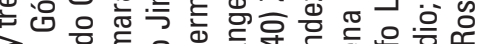

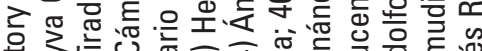

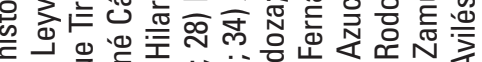

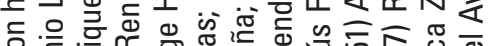

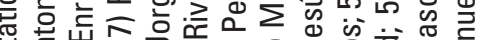

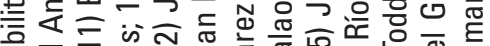
ส 凹

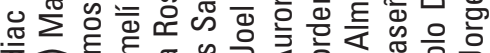

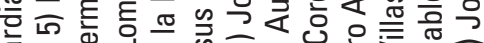
芯

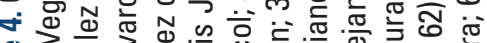

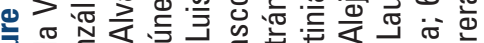

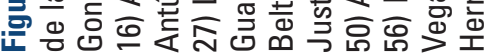




\section{Acknowledgments}

The authors would like to thank Dr. Liliana Lucatero Lecona, of National Medical Center 20 de Noviembre, ISSSTE (Mexico City).

We appreciate the collaboration of each and every one of the members of the various units that have allowed cardiac rehabilitation programs to celebrate 75 years of existence in our country.

\section{Conflicts of interest}

The authors declare that they have no conflicts of interest.

\section{Funding}

The present investigation has not received specific aid from public or commercial sector agencies or non-profit entities.

\section{Ethical disclosures}

Protection of people and animal subjects. The authors declare that no experiments were performed on humans or animals for this study.

Confidentiality of data. The authors declare that no patient data appear in this article

Right to privacy and informed consent. The authors declare that no patient data appear in this article.

\section{References}

1. Feigenbaum E, Carter E. Cardiac rehabilitation services. Health technology assessment report, 1987, no. 6. Rockville (MD): US Department of Health and Human Services, Public Health Service, National Center for Health Services Research and Health Care Technology Assessment. DHHS publication no. PHS 88-3427, 1988.

2. Toscano W. Los ejercicios físicos y la salud en el corpus hipocrático. Consideraciones a tener en cuenta para la educación física [Internet]. [Consultado el 30 de junio de 2018]. Disponible en: http://www.cienciared.com.ar/ra/usr/41/626/calidadevidauflo_i_pp67_82.pdf.

3. Carlos Viesca T, Aranda C, Ramos de Viesca M. El corazón y sus enfermedades en la cultura náhuatl prehispánica. Estudios de Cultura Náhuatl. 2005;36:225-43.

4. Laín Entralgo P. Historia de la medicina. Barcelona, España: Salvat;1978.
5. Painani, los mensajeros del imperio azteca. Consultado el 11 de junio de 2019. Disponible en: http://www.runthehistory.com/2017/09/painani-los-mensajeros-del-imperio-azteca.html.

6. Ruiz L, Devesa I. La medicina de rehabilitación en la segunda mitād del siglo XX. México, Univerdidad Nacional Autónoma de México; 2005.

7. Lerma R. Historia de la rehabilitación en Fuerzas Armadas. Sociedad Mexicana para el Cuidado del Corazón A.C. Rehabilitación Cardiövascular, Prevención y Cardiología del Deporte. Comunicación persononal, 2018.

8. Oertel MJ. Allgemeine Therapie der Kreislauf-Störungen, Kraftabnahme des Herzmuskels, Ungenügende Compensation bei Herzfehlern. Leipzig: F.C.W. Vogel; 1891.

9. Flisser A. La medicina en México hacia el siglo XX. Gac Médíméx. 2009;145:353-6.

10. Guerra F, Chávez N. El valor de la lontoforesis con salicilato de-sodio en el reumatismo cardiovascular. Archivos del Instituto de Cardiología de México. 1945;15(XV):153-60.

11. Mehta N, Khan I. Cardiology's 10 Greatest Discoveries of the $20^{\text {th }}$ Century. Tex Heart Inst J. 2002;29:164-71.

12. De Micheli A. El largo camino hacia la cardiología mexicana de hoy. Gac Méd Méx. 2004;140:347-52.

13. Gofman JW, Jones HB, Lindgren FT, Lyon TP, Elliot HA, Strisower B. Blood lipids and human atherosclerosis. Circulation. 1950;2:161-78.

14. Levine SA y Lown B. "Armchair" treatment of acute coronary thrombosis. J Am Med Assoc. 1952;148(16):1365-9.

15. Morris JN, Heady JA, Raffle PA, Roberts CG, Parks JW. Cō̄nary heart-disease and physical activity of work. Lancet. 1953;265(6795):1053-7.

16. Pashkow F. Issues in contemporary cardiac rehabilitation: a historical perspective. J Am Coll Card. 1993;21:822-34.

17. Mampuya W. Cardiac rehabilitation past, present and future: an overyiew. Cardiovasc Diag Ther. 2012;2:38-49.

18. Certo C. History of cardiac rehabilitation. Physical Therapy. 1985;65:1793-95.

19. Romero T. La rehabilitación cardíaca como punto de partida en la prevención secundaria de la enfermedad coronaria. Rev. méd. ęile. 2000;128:923-34.

20. Ruiz L, Devesa I. La medicina de rehabilitación: El ejercicio de la medicina en la segunda mitad del siglo XX. Tercera parte. Siglo XXI Editores;2005.

21. Pimentel Mercado E. Historia de la rehabilitación cardiaca. Centró Médico Nacional $2^{\circ}$ de noviembre. ISSSTE. Comunicación personal.

22. Férez Santander MS. Historia del Instituto Nacional de Cardiología y su influencia en la Medicina Mexicana. Comarketing Editorial; 2008:-

23. Mehta NJ, Khan IA. Cardiology's 10 Greatest Discoveries of the $20^{\text {th }} \mathrm{Cen}$ tury. Tex Heart Inst J. 2002;29(3):164-71.

24. Reed H, Guazz M, Niebauer J. Cardiac rehabilitation in Europe. Progress in cardiovascular diseases. 2014;56:551-6.

25. Froelicher V, Jensen D, Atwood JE, McKirnan MD, Gerber K, Slutsky R, et al. Cardiac rehabilitation: evidence for improvement in myocardial perfusion and function. Arch Phys Med Rehabil. 1980;61(11):517-22.

26. Entrevista a Marcela Pérez Mancilla, fisioterapeuta del Servicio de Rehabilitación cardiaca del Instituto Nacional de Cardiología, 2016. Comunicación personal.

27. Oldridge N, Furlong W, Feeny D, Torrance G, Guyatt G, Crowe Jet al. Economic evaluation of cardiac rehabilitation soon after acute myocardial infarction. Am J Cardiol. 1993;72:154-61.

28. González M, Fernández de la Vega P, Ruiz Meza J, Leyva M, Ortiz E. Principales hospitales con servicios o programas de RHC en la Giudad de México. Comunicaciones libres del XVIII Congreso Nacional de Cardiología de la Sociedad Mexicana de Cardiología. Archivos del Instituto Nacional de Cardiología; 1993. Abstract 518.

29. Oficio Secretaría de Marina. Comunicación personal, 1996.

30. Cantero Colín R. Historia de la rehabilitación cardiaca. Servicio de rehabilitación cardiaca. Centro Médico Nacional Siglo XXI. IMSS. Comunicación personal. 2018.

31. Heberden W: Some account of a disorder of the breast. Medical transitions. Royal College of Physiscians, 1772. 